Dariusz Iwan

Muzeum i Instytut Zoologii PAN

ORCID 0000-0003-0146-7916

Piotr Daszkiewicz

Instytut Historii Nauki im. L. i A. Birkenmajerów PAN

ORCID 0000-0002-6631-100X

\title{
Koncepcja organizacji pracy w instytucji naukowej - ankiety i opracowania z okresu okupacji (I94 I-1942) w Państwowym Muzeum Zoologicznym w Warszawie
}

\author{
The Concept of Work Organisation in a Scientific \\ Institution - Surveys and Studies from the Occupation \\ Period (194I-1942) at the State Zoological Museum \\ in Warsaw
}

During the Second World War, the State Zoological Museum in Warsaw (PMZ) suffered severe losses. Many workers were killed, and parts of the zoological and book collections were stolen by the Germans as early as 1939 . The Museum became an important centre of the resistance movement, as it became a storage for weapons, explosives, and chemicals used for sabotage. Despite the repressions, the Museum employees tried to continue their work under the occupation and developed a modern model for the functioning of this institution to be implemented after the war. In the archives of the Museum and Institute of Zoology, a folder was found containing the documentation of the surveys conducted in 1941-1942 on the organisation of work and the future structure of the PMZ. This article presents the first analysis of these documents, which turned out to be a valuable source of information on the functioning of scientific institutions during the occupation, as well as on the history of the PMZ itself.

Keywords: State Zoological Museum in Warsaw, history of collections, organisation of scientific work, resistance movement

Słowa kluczowe: Państwowe Muzeum Zoologiczne w Warszawie, historia zbiorów, organizacja pracy naukowej, ruch oporu

W okresie II wojny światowej Państwowe Muzeum Zoologiczne (PMZ) poniosło dotkliwe straty ${ }^{1}$. Szczegółowe fakty i dane na ten temat zostały podane w raporcie Stanisława

1 G. Brzęk, Straty wśród zoologów polskich w następstwie II wojny światowej, „Analecta. Studia i Materiały z Dziejów Nauki" t. 6, 1997, nr 2 (12), s. 173-197. 
Feliksiaka ${ }^{2}$ i opisie zbiorów lepidopterologicznych przechowywanych w $\mathrm{PMZ}^{3}$. Oprócz utraty życia $27 \%$ procent pracowników i współpracowników tej instytucji, zrabowano lub zniszczono znaczącą część kolekcji zoologicznej, księgozbioru, a także aparatury naukowo-badawczej. Już w październiku 1939 roku doszło do spektakularnej akcji tzw. Kommando Paulsen:

S. S. Untersturmfuehrer prof. dr Peter Paulsen wywiózł kilku samochodami ciężarowymi część zbiorów zwierząt (w tym żubry), książek i przyrządów optycznych do Salzburga, jak się okazało w czasie rewindykacji w roku $1946^{4}$.

Zrabowano wtedy nie tylko kolekcje przyrodnicze, ale znaczną liczbę bardzo cennych dzieł z biblioteki PMZ, uważanej za jedną z najważniejszych bibliotek przyrodniczych w tej części Europy5. Feliksiak bardzo trafnie zdefiniował straty PMZ w swoim raporcie, uwzględniając również brak możliwości realizowania działalności naukowej przez pracowników tej instytucji:

W czasie od 1 stycznia 1940 r. do 1 sierpnia 1944 r. Instytucja pod administracją cywilnych władz okupacyjnych przy kilkuosobowym personelu mogła przeprowadzać jedynie prace porządkowo-konserwacyjne nad swoimi zbiorami, jak również złożonymi w depozycie przez inne instytucje, oraz podtrzymywać utajony znicz pracy naukowej. Powstała sześcioletnia przerwa w normalnej naukowej działalności Muzeum, w publikowaniu jego wydawnictw, w jego łączności z instytucjami zoologicznymi w świecie. Wysokość strat z nią związanych jest trudna do ujęcia ${ }^{6}$.

W archiwum Muzeum i Instytutu Zoologii PAN przechowywana jest teczka (sygn. PMZ 99) zawierająca dokumentację ankiet przeprowadzonych w latach 1941-1942 na temat organizacji pracy i przyszłej struktury PMZ. Dokumenty te, dotychczas nieanalizowane, z kilku względów zasługują na opracowanie i opublikowanie. Znajdujemy w nich opis nieznanego epizodu historii PMZ, o którym nie wspomina w swojej monografii Feliksiak, mimo że był pracownikiem naukowym tej instytucji w czasie okupacji i brał aktywny udział w pracach nad ankietą. Inicjatywa ówczesnego kierownictwa PMZ, jaką było rozesłanie i analiza ankiet, była niewątpliwie rozpaczliwą próbą zachowania pozorów normalności w okresie okupacyjnego terroru. Jednocześnie miał to być ważny element w przygotowaniu organizacji pracy PMZ po wojnie, w wolnej już Polsce. Pragnięto udoskonalić model organizacyjny wywodzący się z II RP, a jednocześnie przemyśleć i przedyskutować organizację badań zoologicznych prowadzonych w Polsce. Z oczywistych względów taka ankieta przeprowadzona w okupowanej Warszawie, w specyficznej sytuacji polskich instytucji naukowych, musiała mieć bardzo ograniczony zasięg. Nie można było przecież przesłać

2 P. Daszkiewicz, D. Iwan, Straty wojenne Państwowego Muzeum Zoologicznego - raport Stanisława Feliksiaka (1906-1992), „Pamięć i Sprawiedliwość” 2016, nr 15/1, s. 431-439.

3 Autor podaje, że w 1944 r., tuż po Powstaniu Warszawskim, celowo została spalona kolekcja entomologiczna, w tym około pół miliona okazów motyli; S. Adamczewski. Pracownia lepidopterologiczna i zbiory motyli w Państwowym Muzeum Zoologicznym, „Polskie Pismo Entomologiczne” t. 18, 1949 (1939-1948), s. 225-247.

4 P. Daszkiewicz, D. Iwan, op. cit., s. 435.

5 W. Laszczkowska, Zarys rozwoju Biblioteki Instytutu Zoologicznego Polskiej Akademii Nauk, „Memorabilia Zoologica" 1965, nr 13, s. 107.

6 P. Daszkiewicz, D. Iwan, op. cit., 435-436.

7 P. Daszkiewicz, D. Iwan, H. Kowalski, D. Mierzwa-Szymkowiak, R. Zaborowski, Zygmunt Fedorowicz, Stanisław Feliksiak. 150-lecie Gabinetu Zoologicznego w Warszawie (1818-1968), „Memorabilia Zoologica” 2016, Nowa Seria, nr 1, s. i-xii, 1-202. 
jej zoologom przebywającym w niewoli, ukrywającym się, żyjącym w okupowanej przez Sowietów części Polski, jak i tym, którym w 1939 r. udało się przedostać na Zachód. Jak można wyczytać w jednym z dokumentów, ankiety wysłano ośmiu osobom, a otrzymano sześć odpowiedzi. Niektóre dokumenty zostały sporządzone ręcznie, pomimo prośby organizatorów o korzystanie z maszyn do pisania. W okupacyjnych warunkach nie wszyscy z ankietowanych zoologów mieli dostęp do tych urządzeń, a także do papieru, stąd niektóre odpowiedzi powstały na kartkach wcześniej sporządzonych pism lub na papierze bardzo słabej jakości.

Po upadku Warszawy, od końca 1939 r., PMZ podlegało Komisji Likwidacyjnej Ministerstwa Wyznań Religijnych i Oświecenia Publicznego, która wznowiła oficjalną działalność Muzeum na wiosnę 1940 r. Pierwszym dyrektorem PMZ mianowano Władysława Rydzewskiego (od kwietnia do połowy lipca 1940 r.), a następnie, aż do końca wojny, Kazimierza Tarwida. Prawdopodobnie obaj naukowcy w obliczu projektu władz niemieckich przeniesienia zbiorów przyrodniczych i bibliotecznych do jednego z budynków uniwersyteckich, co groziło likwidacją instytucji, byli inicjatorami dyskusji mającej na celu ratowanie Muzeum. Już 6 września 1940 r. Rydzewski przedstawił dokument zatytułowany „W sprawie organizacji biblioteki". Notatka z początku 1941 r. (prawdopodobnie autorstwa Tarwida) wyjaśnia genezę i cel przeprowadzenia ankiet wśród pracowników:

Jak wynika z rozmów z poszczególnymi pracownikami, istnieje ogólne przekonanie o potrzebie porozumienia się w sprawie ew. zmian w organizacji, systemie pracy, jej zakresu etc. naszej Instytucji. [...] Ankieta będzie składać się z kilku do kilkunastu części. [...] Wyniki jej mają służyć jako materiał orientacyjny dla kierownictwa instytucji co do zamierzeń i projektów pracowników. [...] Odpowiedzi nie są anonimowe, może być jednak zastrzeżone nie podawanie nazwisk do ogólniejszej wiadomości [...]. Ani fakt istnienia ankiety, ani jej wyniki nie nadają się do rozpowszechnienia.

W archiwum MilZ PAN znajdują się dokumenty, które świadczą o tym, że przygotowano dwa zbiory ankiet: „seria $A^{\prime \prime}$ (numery 1-4) dotyczyła organizacji pracy naukowej i muzealnej oraz struktury instytucji, natomiast „seria B” (numer 1) wyboru dyrektora. W trakcie prac nad poszczególnymi zagadnieniami okazało się, że ich zakres wykracza poza problemy samego PMZ, które jako sukcesor Narodowego Muzeum Przyrodniczego odgrywało w okresie dwudziestolecia międzywojennego istotną rolę w tworzeniu instytucji naukowych niepodległego państwa polskiego. Świadczą o tym chociażby takie opracowania jak: „Zadania Muzeum Zoologicznego w zakresie archiwizacji przejawów życia zoologicznego kraju”, "Archiwizacja zbiorów naukowych” (marzec 1942 r., S. Feliksiak), czy też „Ankieta w sprawie katalogów zoologicznych Polski” (maj 1942 r., S. Adamczewski).

Wśród organizatorów i ankietowanych wszystkie zidentyfikowane nazwiska należą do wybitnych zoologów, którzy odgrywali kluczową rolę w organizacji badań zoologicznych z zakresu systematyki i faunistyki, a także tworzyli zręby polskiej ekologii. W kontekście czasów okupacji warto także przypomnieć, że kilku z nich było bohaterami ruchu oporu, żołnierzami ZWZ i AK, wykazali się bohaterstwem i ogromnym poświęceniem. W Muzeum, mieszczącym się w budynku przy ul. Wilczej 64, działała konspiracyjna komórka Armii Krajowej. W muzealnej bibliotece przechowywano podziemne wydawnictwa, natomiast w służbowym mieszkaniu Feliksiaka, które znajdowało się w budynku 
$\mathrm{PMZ}$, przygotowywane były materiały dla akcji „N"8. Sam Feliksiak, tak jak ówczesny dyrektor PMZ Tarwid (pseudonim „Antoni”), był oficerem AK i brał udział w Powstaniu Warszawskim, walcząc pod pseudonimem „Romb” na Czerniakowie, lasach Kabackich i Chojnowskich ${ }^{9}$. Irena Cissowska ${ }^{10}$, w okresie okupacji sekretarka Tarwida, tak wspominała ten okres:

W piwnicach i na strychu Muzeum został zorganizowany magazyn broni i materiałów wybuchowych, a funkcję magazyniera pełnił Kazimierz Tarwid. Profesor opowiadał mi po jednym z nalotów sowieckich na Warszawę, że był zmuszony zdekonspirować się częściowo przed dwoma woźnymi i wezwać ich do pomocy przy znoszeniu pak trotylu ze strychu do piwnic. W piwnicy stały także i stale były uzupełniane wielkie beczki z chlorkiem żelaza. Oficjalnie służyć miał on do osuszania gmachu i w części spełniał to zadanie, ale przede wszystkim, służył zmieszany w odpowiedniej proporcji z sublimatem i wodą, do niszczenia wagonów kolejowych. Ośki wagonów niemieckich transportów wojskowych przeżerała ta mieszanina ponoć już po 100 kilometrach i wagon "siadał”. Wyników tej naszej działalności nie widziałam, ale dr Jan Żabiński „Franciszek” mawiał „podlewajcie, podlewajcie, to daje doskonałe rezultaty". Tak więc działalność sabotażową, dzięki przemyślności naszego szefa, w całości finansowali Niemcy ${ }^{11}$ !

Oficerami AK prowadzącymi działalność konspiracyjną byli również Stanisław Adamczewski ${ }^{12}$, Władysław Rydzewski ${ }^{13}$ i Tadeusz Jaczewski ${ }^{14}$, pracownicy naukowi PMZ uczestniczący w opracowaniu ankiety. W takim właśnie kontekście - okupacyjnego zarządu instytucji, niemożności kontynuowania normalnej pracy muzealnej i naukowej, walki o uratowanie przed Niemcami dorobku wielu pokoleń polskich przyrodników, a także funkcjonowania aktywnej komórki ruchu oporu w PMZ - należy analizować „akcję ankietową”. W teczce archiwalnej PMZ znajduje się także nadbitka artykułu opublikowanego w 1920 r. w "Nauce Polskiej" na temat organizacji badań naukowych w Polsce, którego autorem był nieżyjący od 1932 r. Konstanty Janicki. Nie wiadomo, czy tekst ten miał służyć jako pomoc w refleksji o organizacji badań zoologicznych, czy też trafił do teczki z ankietami przypadkowo.

Pierwsza z rozesłanych ankiet zawierała bardzo typowe dla przyrodniczej instytucji muzealnej pytania dotyczące „drogi okazu” (nabytek lub wypożyczenie), „drogi książki”,

8 W. Laszczkowska, Janina Rożnowska-Feliksiakowa (1909-1994), „Przegląd Zoologiczny” t. 39, 1995, nr 1-2, s. 8.

9 G. Brzęk, Prof. dr hab. Stanisław Feliksiak (1906-1992) Obituary, "Przegląd Zoologiczny” t. 39, 1995, nr 1-2, s. 14.

10 Irena Cissowska z domu Ciszkiewicz (1923-2011), żołnierz AK, pseudonimy „Iwicka” i „Irena”. W zbiorach MilZ PAN znajduje się kolekcja entomologiczna zebrana przez jej ojca, Henryka Ciszkiewicza (1896-1940), który był ofiarą zbrodni katyńskiej.

11 L. Andrzejewska, I. Cissowska, A. Hilbert-Ilkowska, E. Dąbrowska-Prot, Kazimierz Tarwid (9 IX 1909-24 XII 1988), „Wiadomości Ekologiczne” t. 36, 1990, nr 1-2, s. 67-76.

12 Stanisław Adamczewski (1909-1987), entomolog, wybitny specjalista w dziedzinie systematyki i ekologii motyli, pionier badań nad fauną motyli miast, a także Puszczy Białowieskiej, po powrocie z niemieckiej niewoli w 1940 r. opiekował się kolekcją motyli, zasłużony dla ratowania zbiorów PMZ w okresie Powstania i odbudowie instytucji po wojnie, syn prof. Stanisława Adamczewskiego (1883-1952), wybitnego historyka literatury; G. Winiarska, Pamięci prof. Dr Stanisława Franciszka Adamczewskiego (1909-1987), „Wiadomości Entomologiczne" t. 10, 1991, nr 2, s. 121-125.

13 J.A. Czyżewski, Rydzewski Władysław (1911-1980), [w:] S. Feliksiak, Słownik biologów polskich, Warszawa 1987, s. 464-465.

14 K. Kowalska, Jaczewski Tadeusz Franciszek Antoni (1899-1974), [w:] S. Feliksiak, Słownik biologów polskich, s. $220-221$. 
poszukiwań dokumentów w archiwum, pracy naukowej. Stanisław Feliksiak, w odpowiedzi z 13 marca 1942 r. zatytułowanej „W sprawie archiwizacji zbiorów naukowych”, podkreślał znaczenie szybkiej rejestracji, konserwacji i odpowiedniego umieszczenia w zbiorze muzealnym otrzymywanych okazów, zwracając w ten sposób uwagę na odpowiedzialność instytucji przyjmującej materiały badawcze. Zwracał także uwagę na konieczność rozdziału funkcji naukowca i kustosza/opiekuna zbiorów:

Wydzielone grupy wędrują do poszczególnych działów i aż do chwili posortowania ich na gatunki, co najczęściej odbywa się w czasie przygotowania publikacji, nie ma o nich nigdzie śladu. W celu orjentacji należałoby jednak i zbiory nieopracowane przeprowadzać przez kartotekę w miarę ich stopniowego rozsortowywania na coraz to mniejsze jednostki systematyczne aż do rodzaju włącznie.

Odrębna ankieta dotyczyła zbiorów bibliotecznych, zwracano uwagę na sposób katalogowania, konieczność prowadzenia ewidencji tymczasowej, podziękowania za darowizny, kontroli obrotu materiałów, prowadzenia i prezentacji spisu nowości oraz katalogu działowego i przedmiotowego. Z czasem biblioteka zostałaby przekształcona w odrębny dział PMZ, a jej pracownicy, oprócz wielu innych kwalifikacji, mieli charakteryzować się znajomością języków obcych, zamiłowaniem do pracy i porządku, kaligraficznym charakterem pisma, a nawet... poczuciem humoru.

Ważnym tematem ankiet była kwestia zasad i procedur przeprowadzania wyboru dyrektora PMZ, a więc problemu autonomii instytucji naukowych, oczywiście w kontekście ich funkcjonowania w przyszłej wolnej Polsce. Bardzo poważnie informowano ankietowanych (choć było ich tylko ośmiu), oczekując na „odpowiedź w ciągu tygodnia”, o procedurach postępowania z dostarczonymi odpowiedziami:

Poprzednie ankiety i szereg następnych z tej serii są poświęcone zebraniu materiałów i opinii. Niniejsza rozpoczyna serię konkretych wniosków postawionych przez biorących udział w naszych rozważaniach i wymagających zdecydowania [przekreślony wyraz]. Wnioski te będą podawane przeważnie grupami [przekreślony wyraz]. Odpowiedzi na nie traktowane będą jako pewnego rodzaju głosowanie, wynik którego jest wiążący zasadniczo dla prowadzących ankietę w formułowaniu dalszych pytań.

O swobodzie wypowiedzi i dużym zaangażowaniu uczestników świadczy wymiana opinii na temat zasad i procedur wyboru dyrektora. Tarwid w swoim opracowaniu pisze:

Może byłoby lepiej dla instytucji, gdyby dyrektor nie był mianowany przez ministra, lecz wybierany przez pracowników naukowych ze swego grona na pewien okres, z prawem reelekcji i z ew. zatwierdzeniem wyboru przez władzę przełożoną. Zdecydowanie się na obieralność kierownika miałoby ważkie następstwa dla naszych stosunków wewnętrznych personalnych i organizacyjnych, związana z tym byłaby kwestia zapewnienia ciągłości „polityki” muzealnej; zagadnienie centralizacji organizacji wewn.; byłyby dalej do rozstrzygnięcia sprawy formalnej organizacji: kto wybiera? Jakie kwalifikacje musi posiadać kandydat? Czy, kto i na czyje ręce ma prawo zgłaszać od wyników wyborów?

Rydzewski w odpowiedzi z dnia 25 lipca 1941 r. uznał takie stanowisko za błędne. Był przeciwnikiem możliwości obejmowania funkcji dyrektora wyłącznie przez pracowni- 
ków PMZ, gdyż zamykałoby to drogę osobom z poza Muzeum. Uważał także, że roczna kadencja prowadziłaby do niezdrowego współzawodnictwa i faworyzowała postawy karierowiczostwa. Jego zdaniem kandydatury powinna proponować konferencja pracowników i przedstawiać do zatwierdzenia władzy zwierzchniej. Jakakolwiek ingerencja osób z zewnątrz byłaby niezgodna ze statutem PMZ. Rydzewski uważał, że dyrektor Muzeum nie musi być wybitnym zoologiem, ale sprawnym administratorem i organizatorem. $\mathrm{Na}$ stanowisko powinien być wybierany bezterminowo, jednak konferencja pracowników miałaby prawo udzielić mu „votum nieufności”, o czym informowana byłaby władza zwierzchnia.

Odrębną ankietę przeprowadzono na temat katalogów zoologicznych Polski. Oczywiście, podkreślano centralną rolę PMZ w prowadzeniu krajowych badań, szczególnie faunistycznych. Przy okazji przeprowadzono analizę materiału wykorzystanego w dotychczasowych opracowaniach fauny Polski (1 maja 1943 r., S. Adamczewski), m. in. udzielano wskazówek, takich jak:

[aby] przyszłe opracowania poszczególnych grup były pozbawione zasadniczych błędów, żeby przedstawiały materiał źródłowy do dalszych badań, na którym możnaby się z zaufaniem opierać, ażeby uwalniały od ponawiania żmudnych poszukiwań bibliograficznych przy każdym nowym temacie. W tym celu, każde opracowanie katalogowe pewnej grupy zwierząt z fauny Polski powinno składać się z trzech części: wyszczególnienie materiału źródłowego z literatury co stanowiłoby właściwy katalog, osobne wyszczególnienie własnego materiału autora katalogu, ewentualny krytyczny komentarz do danych literatury w nawiązaniu do własnych danych.

Proponowano także zasady opracowywania i katalogowania rezultatów wypraw naukowych. Jedna z ankiet, zatytułowana "Korzystanie ze zbiorów zoologicznych PMZ", miała doprowadzić do opracowania regulaminu korzystania ze zbiorów. Stanisław Adamczewski uznawał, że w Muzeum zbyt duże grono osób było odpowiedzialne za poszczególne kolekcje, a także wskazywał negatywne skutki funkcjonowania zbiorów zoologicznych wynikające z konfliktu interesów pomiędzy funkcją kustosza i naukowca. Pisał, że brak jest specjalistów od wielu dużych grup systematycznych zwierząt (np. chrząszczy), co sprawia, że materiały przechowywane w kolekcjach Muzeum są nieewidencjonowane, a więc niedostępne do badań. Podkreślał, że problem nie ma charakteru wyłącznie finansowego:

błędnym było ogólnie przyjęte mniemanie że są to konsekwencje wyłącznie szczupłej ilości personelu. Powstawały one również na skutek wad organizacyjnych pracy Muzeum. Przecież oczywistą jest sprawą, że gdyby specjalistów była trzy lub cztery razy większa liczba to zawsze jeszcze pozostawałaby jeszcze dość znaczna ilość grup nieobsadzonych i niebudzących niczyjego zainteresowania. Błąd polega na stosowaniu takiej organizacji pracy, przy której zbiory jako Niepodzielna Całość, jeśli chodzi o główne zasady konserwacji i ewidencji majątku Muzeum, są dzielone na cały szereg enklaw poddanych bardzo niejednolitej gospodarce, za którą odpowiedzialna jest cała plejada zupełnie przypadkowych kustoszy i opiekunów. Jedynym czynnikiem odpowiedzialnym za całość jest dyrektor Muzeum, który jed- 
nak nie ma w swym ręku aparatu dozwalającego na kontrolę każdego fragmentu zbiorów w stopniu wystarczającym i nie posiada żadnej ewidencji majątku zbiorów - jest gospodarzem nie znającym stanu swojego posiadania. Ponieważ zaniedbania w gospodarce zbiorami odnosiły się w różnych grupach właśnie do strony ewidencyjnej i konerwacyjnej zastanówmy się czy nie możnaby rozdzielić funkcji kustosza wynikającej z jego pracy przy zbiorach na funkcję Konserwatora Naukowego oraz funkcję Konserwatora Technicznego.

Wiele uwagi w ankietach poświęcono także organizacji pracy i przedziału czasu, który pracownicy mogą poświęcać na własne badania naukowe, rozróżnieniu prac instytucjonalnych i indywidualnych, okresowych i trwałych, wzorom formularzy, wymiarom etykiet, probówek i słoi, określaniu wartości naukowej okazów, tworzeniu wystawy fauny krajowej, organizacji zjazdów i konferencji, budowie nowego budynku, stacji ornitologicznej, podziałowi zbiorów na grupy taksonomiczne. Oczywiście odpowiedzi na tak sformułowane problemy, zważywszy na indywidualność i charakter ankietowanych, dawały sprzeczne rezultaty. Niemożliwym było stworzenie „idealnego" modelu narodowego muzeum zoologicznego dla przyszłej wolnej Polski. Bardzo realistycznie jednak, w piśmie z dnia 10 lutego 1941 r., podkreślono, iż „organizacja i przyszłość Muzeum jest zależna od ogólnej koniunktury".

Historia dopisała dalszy, jakże okrutny i bezwzględny, ciąg wydarzeń, gdy tuż po Powstaniu, w ramach zemsty na Warszawie, Niemcy podpalili budynek Muzeum. Autorzy i uczestnicy ankiety, w obliczu realnego zagrożenia śmiercią, ratowali unikatowe kolekcje zoologiczne i księgozbiór przed spaleniem. Przeprowadzenie w czasie okupacji „akcji ankietowej" nie mogło odegrać żadnej praktycznej roli w funkcjonowaniu PMZ i nauki polskiej. Jednak dokumenty przechowywane w archiwum MilZ PAN są świadectwem bohaterstwa, patriotyzmu i chęci powrotu do „normalności” naukowców funkcjonujących w okupowanej Warszawie.

Uniwersalność i ponadczasowość stawianych w ankietach pytań powinna być inspiracją dla reformatorów nauki polskiej, szczególnie w kontekście historii powołania w 1952 r. Polskiej Akademii Nauk oraz licznych kolejnych reform strukturalnych i funkcjonalnych instytutów badawczych PAN, a także starań o reaktywację Narodowego Muzeum Przyrodniczego. W opracowaniu (seria A, nr 4) z 1942 r. główny wniosek podsumowujący dyskusję naukowców zawarty został w punkcie drugim: „Ramy organizacyjne instytucji, które będziemy mogli jej nadać po wojnie i które byłyby punktem wyjściowym dla dalszej ewolucji instytucji":

Wysuwane były następ[ujące] możliwości:

a/ Muzeum jak przed wojną: „blok” magazynów i pracowni o jednolitej strukturze, z satelitą w postaci Stacji Bad[adnia] W[ędrówek] Pt[aków]/Ornitologicznej/ i z nast[ępnie] ew[entualnie] dwiema drogami rozwojowymi:

1 - nacisk na pracę naukową /w typie dotychczasowym/ z ew[entualną] zmianą nazwy „Muzeum” na „Instytut”.

2 - podkreślenie muzealności i dążenie do szybkiej odbudowy wystawy. [...]

b/ Muzeum podzielone na mniej więcej samodzielne co do pracy "Instytuty" wydzielone według grup specjalistów. Podziałowi podlegają tak pracownicy, jak i rów- 
nież zbiory i biblioteka. Administracja wspólna. Kierunki rozwojowe niewątpliwie rozbieżne dla poszczególnych „Instytutów”.

\section{Bibliografia}

Adamczewski S., Pracownia lepdopterologiczna i zbiory motyli w Państwowym Muzeum Zoologicznym, „Polskie Pismo Entomologiczne” t. 18, 1949 (1939-48), s. 225-247.

Andrzejewska L., Cissowska I., Hilbert-Ilkowska A., Dąbrowska-Prot E. , Kazimierz Tarwid (9 IX 1909-24 XII 1988), „Wiadomości Ekologiczne” t. 36, 1990, nr 1-2, s. 67-76.

Brzęk G., Prof. dr hab. Stanisław Feliksiak (1906-1992) Obituary, "Przegląd Zoologiczny” t. 39, 1995, nr 1-2, s. 13-17.

Brzęk G., Straty wśród zoologów polskich w następstwie Il wojny światowej, „Analecta. Studia i Materiały z Dziejów Nauki" 1997, t. 6, nr 2 (12), s. 173-197.

Daszkiewicz P., Iwan D., Straty wojenne Państwowego Muzeum Zoologicznego - raport Stanisława Feliksiaka (1906-1992), „Pamięć i Sprawiedliwość” 2016, nr 15/1, s. 431439.

Daszkiewicz P., Iwan D., Kowalski H., Mierzwa-Szymkowiak D., Zaborowski R., Zygmunt Fedorowicz, Stanisław Feliksiak. 150-lecie Gabinetu Zoologicznego w Warszawie (1818-1968), „Memorabilia Zoologica” 2016, Nowa Seria, nr 1, s. i-xii, 1-202.

Feliksiak S., Słownik biologów polskich, Warszawa 1987.

Laszczkowska W., Zarys rozwoju Biblioteki Instytutu Zoologicznego Polskiej Akademii Nauk, "Memorabilia Zoologica” 1965, nr 13, s. 107.

Laszczkowska W., Janina Rożnowska-Feliksiakowa (1909-1994), „Przegląd Zoologiczny” t. 39, 1995, nr 1-2, s. 7-11.

Winiarska G., Pamięci prof. Dr Stanisława Franciszka Adamczewskiego (1909-1987), „Wiadomości Entomologiczne” t. 10, 1991, nr 2, s. 121-125.

\section{Podziękowania}

Autorzy pragną podziękować Pani Majce Główce z Archiwum Muzeum i Instytutu Zoologii PAN w Warszawie.

prof. dr hab. Dariusz Iwan, od 1988 r. pracownik Muzeum i Instytutu Zoologii PAN w Warszawie; od 1991 r. kierownik Muzeum Zoologicznego w MilZ PAN; jego praca naukowo-badawcza obejmuje problematykę związaną z entomologią (zróżnicowanie fauny Polski, filogeneza i klasyfikacja chrząszczy z rodziny Tenebrionidae, przystosowanie owadów do życia w warunkach pustynnych); opublikował ponad 100 oryginalnych prac naukowych z dziedziny entomologii, muzealnictwa przyrodniczego i historii zoologii, w tym 6 opracowań monograficznych, w których opisał ponad 170 nowych dla nauki gatunków i 25 rodzajów chrząszczy.

e-mail: darek@miiz.waw.pl 
dr hab. Piotr Daszkiewicz, prof. PAN, przyrodnik i historyk nauki, doktor nauk biologicznych, doktor habilitowany nauk humanistycznych, profesor w Instytucie Historii Nauki PAN w Warszawie i pracownik Office Français pour la Biodiversité, wieloletni pracownik Narodowego Muzeum Historii Naturalnej w Paryżu i współpracownik paryskiej „Kultury” i Instytutu Literackiego w Maisons-Laffitte; interesuje się historią nauk przyrodniczych, historią poznawania Puszczy Białowieskiej i badań nad żubrem, historią kolekcji i muzeografii przyrodniczej oraz historią polsko-francuskiej współpracy naukowej.

e-mail: piotrdas@yahoo.fr

Data zgłoszenia artykułu: 28 lutego 2021

Data przyjęcia do druku: 9 kwietnia 2021 